\title{
IMPACT OF THE NEW DISTRIBUTION CAPABILITY (NDC) STANDARD ON FUTURE AIRLINE DISTRIBUTION - A CRITICAL ANALYSIS
}

\author{
Yvonne Ziegler \\ Frankfurt University of Applied Sciences, Frankfurt, Germany \\ Jörg Troester \\ Hahn Air Lines \\ Abdul Mu'ti Sazali \\ Frankfurt University of Applied Sciences, Frankfurt, Germany
}

\begin{abstract}
In 2012 IATA has initiated a new communication standard in airline distribution called New Distribution Capability (NDC) that will enable airlines, IT providers, and travel agents to work together to create new capability in the distribution of airline products and services as well as to simplify the business. NDC has been introduced to solve limitations of the existing programs in the distribution system and to represent the modernization of future air travel distribution. NDC standard intends to give a potential impact on future airline distribution where airlines will have wider opportunities to directly interact with intermediaries and reduce commission fees to the Global Distribution System (GDS). This study, in particular, confirms that airline distribution specialists firmly believe that NDC constitutes an important development in the airline industry and, while still being in its development stage, it clearly has the potential to address today's market issues and to solve tomorrow's challenges.
\end{abstract}

Keywords: New Distribution Standard, Airline Distribution, Global Distribution Systems.

Professor Dr Yvonne Ziegler: Frankfurt University of Applied Sciences, Germany. E-mail: yziegler@fb3.fra-uas.de (corresponding author)

Jörg Troester: Hahn Air Lines, Germany. E-mail: j.troester@hahnair.com

Abdul Mu'ti Sazali: Frankfurt University of Applied Sciences, Germany. E-mail: sazali@stud.fra-uas.de 


\section{INTRODUCTION}

\subsection{Background of the research}

The aviation industry has gone through drastic changes in the past 20 years. The global development of the Low Cost business model, the depression of the aviation market following the $9 / 11$ attacks and the high oil price has put enormous pressure on established network carriers to decrease their costs. As a consequence network carriers were searching for cost cutting potentials in all business segments. One of the big cost blocks were distribution costs, especially the costs of the Global Distribution Systems (GDS).

In parallel the digital technology spurred people to create innovations in business. In the airline industry, digital technology has significantly changed the commercial environment especially in addressing customers' needs during the process of searching, planning, and buying air products (IATA, WTAAA, T2 Impact, and Atmosphere Research Group, 2015). Advanced technology is not only enabling airlines to modify their products, personalize it according to the customer's needs, and analyze current trends, but also providing customers the opportunity to design their preferred air products (IATA and Atmosphere Research Group, 2015).

In 2015 , more than 3.5 billion people worldwide used commercial airline flights and it is projected to reach 7 billion passengers by 2034 (IATA, 2015). In this internet era, an increasing share of passengers plan, search, and buy airline tickets online. This phenomenon has encouraged airlines to more and more sell and distribute their tickets through the internet (Harteveldt, 2012).

In the 1970s, when airlines were connected to travel agents through the IBM green screen system, airlines' ancillary air products couldn't be sold because of the primitive nature of that IT system. The introduction of Electronic Miscellaneous Documents (EMD), the electronic successor of Miscellaneous Charges Orders (MCO), solved the limitations in online sales of ancillary products in today's distribution systems in the best possible way for the green screen technology, but still left gaps for the direct and indirect distribution.

With the transparency created by the internet, customers are becoming more demanding. For every single product that they buy, they want to know what the value of the product is, and what benefits they get for the price that they pay (Hoyles, 2015). However the existing IT tools cannot meet those customers' needs. Therefore, in early 2012, IATA launched a program 
named New Distribution Capability (NDC) to address these limitations (Hoyles, 2015; Tyler, 2013).

\subsection{Research Objective}

This research is aimed to

- $\quad$ explain the principles of airline distribution channels,

- $\quad$ evaluate the existing distribution channels,

- $\quad$ give an outlook on the future of distribution channel,

- $\quad$ analyze advantages and disadvantages of New Distribution Capability (NDC), and

- $\quad$ describe potential consequences of NDC.

In the conclusion, this research paper will come up with a SWOT analysis for the implementation of this new standard and give recommendations to the stakeholders.

\subsection{Research Methodology}

This research is conducted in two parts. The first part is a non-empirical literature based research methodology where existing publications on the New Distribution Capability (NDC) are critically reviewed. Kothari (2004) explains that in conducting analytical research, researchers have to use information from credible resources which are already available and publicly accepted. When the information and facts are collected, the researchers analyze them to make a critical evaluation of the findings and current situation.

In the second part an empirical research methodology is used. Distribution experts of the airline industry will be invited to answer an online survey on the future of distribution and NDC, in order to complement the results of the literature review.

\section{AIRLINE DISTRIBUTION CHANNELS TODAY}

\subsection{Airline distribution policy}

Distribution policy is a part of marketing management where producers get in contact with the final customers for the sale of their products. This contact can be direct or indirect (Shaw, 2011). In the airline industry, airlines use both direct and indirect distribution channels to sell 
air products. In direct distribution, airlines sell the products directly through their ticketing offices or websites, and in indirect distribution the airlines use third party distributors such as travel agencies and online travel agencies (Harteveldt, 2012).

Prior to the existence of airline websites as one of the direct distribution channels, approximately $80 \%$ of airline products were sold through indirect channels. Since the emerging of direct online sales (airlines website and online travel agents), approximately 50\% of the global bookings are managed through this channel (Open Axis Group, 2010).

\subsection{Direct distribution channels}

The main advantage of a direct distribution channel for the airline is that normally only a reduced commission, kick-back or fee has to be paid to channel intermediaries. Direct channels become significant to airlines in distributing their products through airline ticket offices, call centers, and the internet-based sales channel (Shaw, 2011). Figure 1 shows a screen shot of the Qatar Airways web page.

Figure 1: Direct distribution channel (Source: Qatar Airways, 2017)

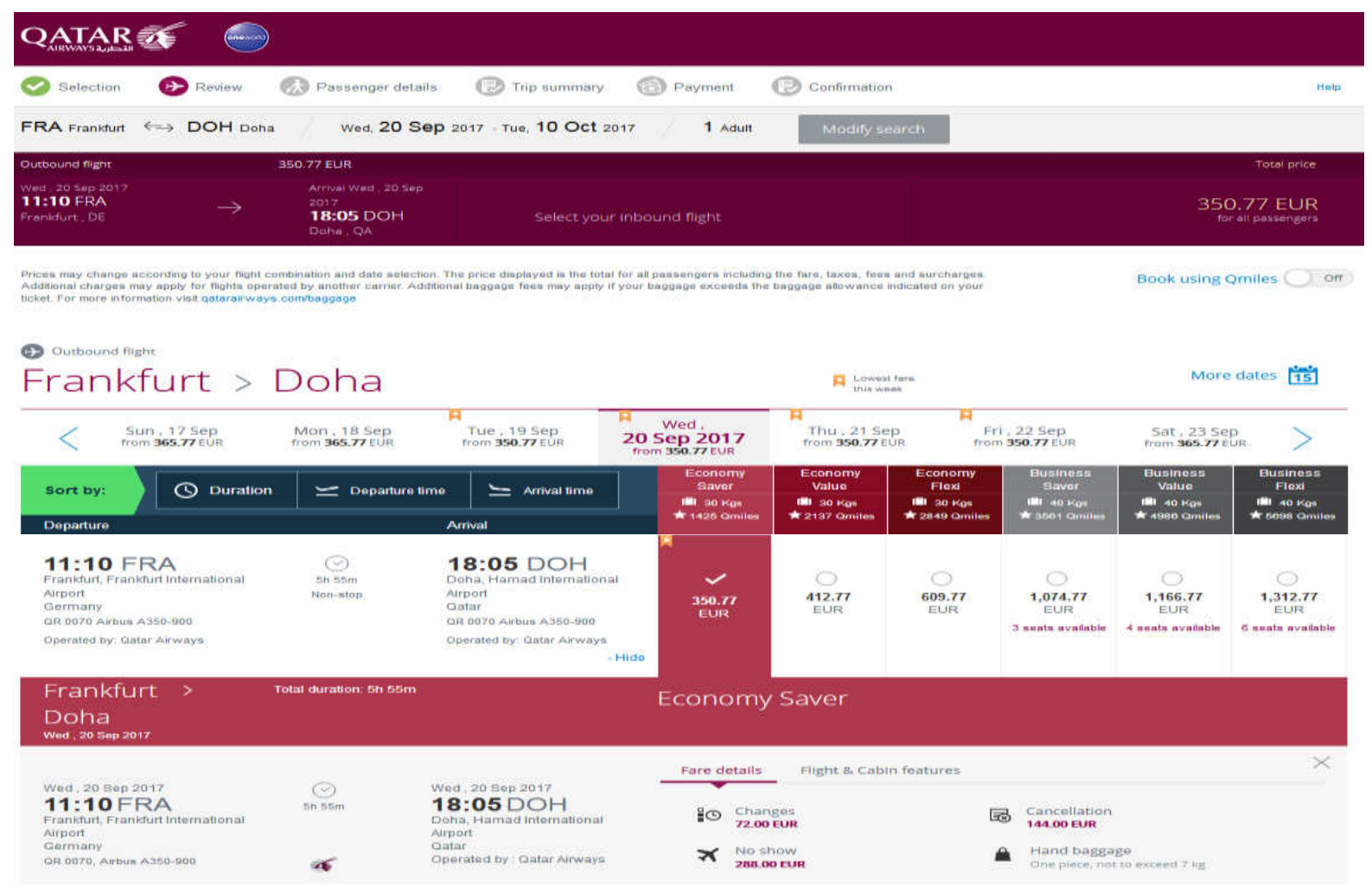

Since decades, the websites of airlines and other travel intermediaries have significantly changed customers' behavior in searching, comparing, and purchasing airline tickets. The mature stage of this new direct channel helps airlines not only to sell but also to personalize 
products and services and to give another new shopping experience to the end customers (Open Axis Group, 2010).

Besides, airline's websites also give an opportunity to customers to choose the products based on the value that they expect. Today an airline's website has a significant role in distributing airline's products through direct distribution channels - especially as mobile commerce registers an increasing importance in both developed and developing countries. Larger airlines can directly present their offers through their own website with a lot of personalized offers (IATA, 2013).

Taneja (2011) maintains that in order to increase profit, airlines should enhance direct distribution channels, increase ancillary revenue, and reduce distribution cost by optimizing the use of indirect channels.

Direct access to customers and their data become increasingly important for airlines. Direct distribution channels are almost exclusively used by low cost carriers (LCCS). In 2012, LCCs successfully generated about twice as much of their bookings through website direct channels compared to full service/flag carriers (Harteveldt, 2012). Most LCCs use direct distribution channels to generate bookings through their website in order to avoid high costs from indirect distribution processes including but not limited to GDS costs plus travel agency kick-back, operation of an electronic ticketing database and money repatriation.

On the other hands, it is still difficult for airlines to achieve their sales targets by only relying on direct channels due to geographical coverage limits and technological limitations of the online channel. Therefore, the role of indirect channels (mainly travel agency) is still crucial for the airline business (Shaw, 2011).

\subsection{Indirect distribution channels}

To achieve a wide geographical coverage, airlines use travel agencies as an indirect distribution channel to distribute air products to the end customers. In the past, airlines paid commissions to the agents for every transaction (Shaw, 2011). In many markets this has already changed. Airlines switched to a zero commission policy and the agents are charging service charges to the end customer. However airlines still pay incentive to travel agents as well as high GDS fees. For some airlines, the costs in selling tickets through an indirect channel are 20-times more expensive compared to direct channels (Harteveldt, 2012). However, airlines are not able to avoid indirect channels due to their limitations in covering their entire market (Taneja, 2011). 
Some passengers like to be directly served by the travel agents staff for advice, help, or personalization of the travel. However, the presence of travel agents as airlines indirect channel is considered suboptimal in some areas such as in providing rich airlines content, personalizing products, and selling ancillary products (Hoyles, 2015).

Shaw (2011) underlined that, in recent years, direct selling through airline websites has significantly increased airlines sales since people tend to choose buying through a direct online channel rather than going to a sales office or traditional travel agency. As a consequence the travel agency's business concept has also transformed from traditional sales into digital sales namely online travel agencies (OTAs) (see figure 2) (O'Connell and William, 2011).

Figure 2: Indirect distribution channel through Online Travel Agent (Source: www.kayak.com)

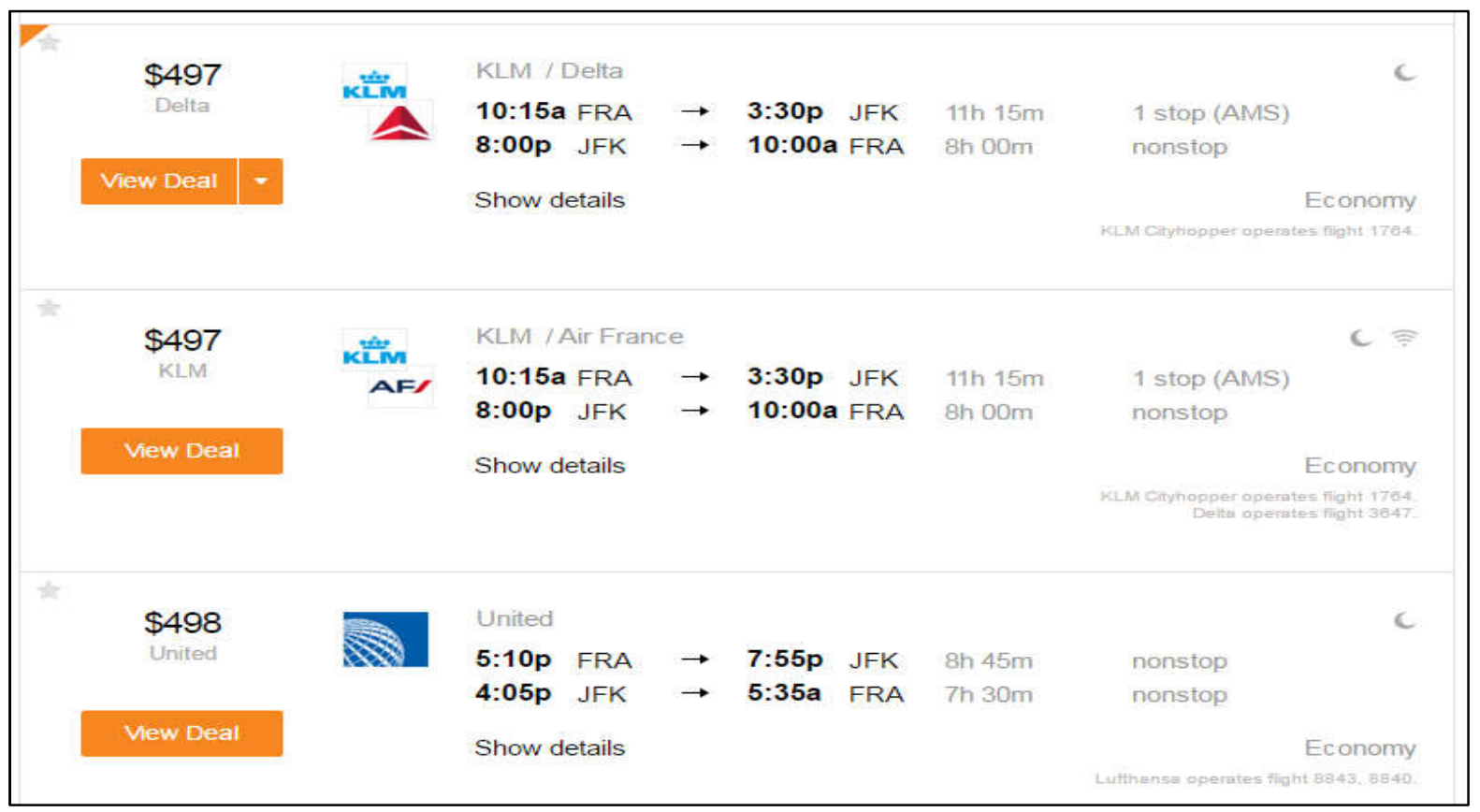

While Online Travel Agents (OTAs) are now an established distribution channel, currently meta search engines (like Google and tripadvisor) are an emerging indirect distribution channel that provides new shopping experience to travelers

A recent analysis from the Open Axis Group (2010) shows that while travelers can go through OTAs to search and purchase air tickets, they cannot get full information about the value they purchased.

Whilst traditional travel retail channels have their own niches in some specific segments (Shon et al., 2003), Airline websites and OTAs dominate the majority of tickets sales in many 
markets, and it is predicted to continue growing (O'Connell and William, 2011). However, there are inherent limitations built-in the current distribution standard that might restrict airline websites and OTAs to grow (Open Axis Group, 2010). Furthermore, past research has shown that legacy airline business strategies, such as GDS by-pass to exclude downstream players or vertical integration to compete with rivals, have created a negative impact on the business performance of airlines (Cheng et al., 2012).

\subsection{The role of GDS and GDS Companies}

A Global Distribution System (GDS) is used as a primary reservation tool that enables third party intermediaries (mainly travel agencies) to access schedule, allotment and price information, create reservations and issue tickets in real time (Coza, 2014). There are three important GDS companies that are known worldwide; Travelport (Galileo, Apollo, Worldspan), Amadeus and SABRE (Coza, 2014). Other GDS of more regional importance are Travelsky, Infini and Topaz.

In today's airline distribution, airlines together with third parties (OAG/ Innovata and ATPCo) file fares and schedules and deliver those to the GDSs. Allotment information are made available in the GDS through an online interface between the airline's CRS and the GDS. Travel agents then will search for schedules, available flights and prices in the GDS and finally create a reservation in the GDS. The GDS finally sends a copy of the reservation to the airline CRS and those will be the last party that know who have purchased the tickets (IATA, 2013). Please refer to figure 3.

Figure 3: Flight Distribution Today (Source: IATA, 2016d, pp. 11)

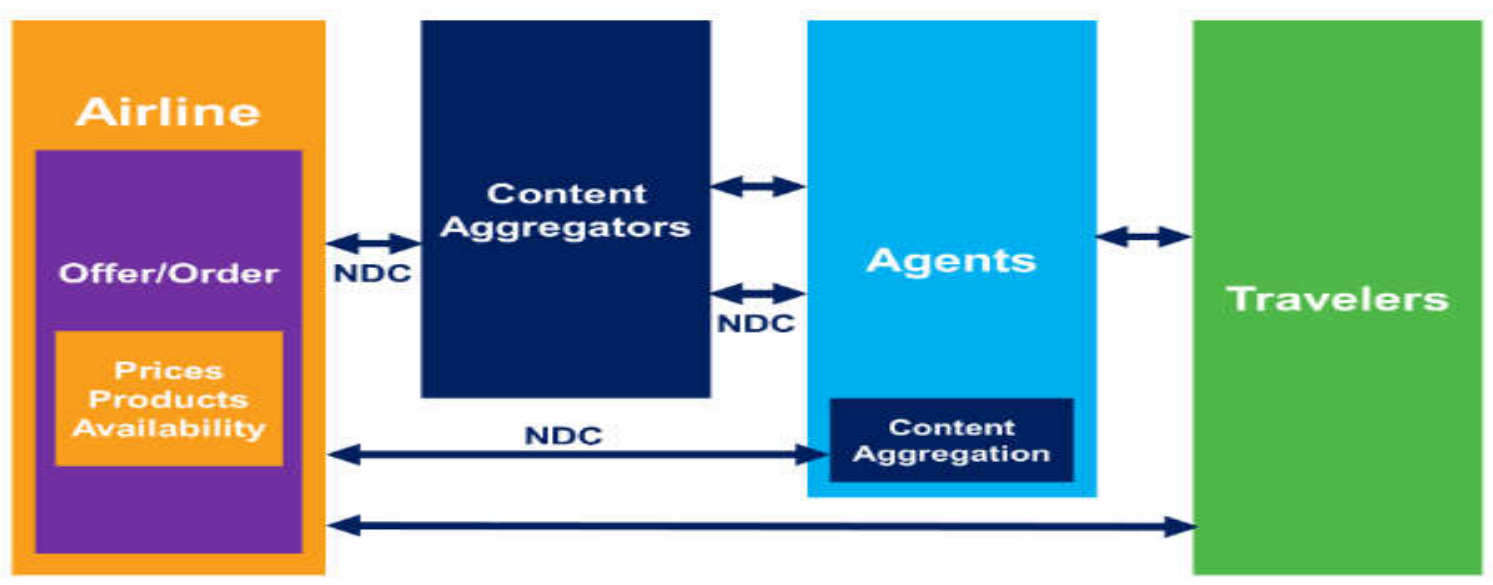

GDS has facilitated airlines in selling their products and still approximately $50 \%$ of airline bookings are channeled via a GDS; this means that the GDS has still a significant role in the 
airline indirect distribution channel (Harteveldt, 2012). Airlines used to pay a US $\$ 12$ booking transaction fee per segment to the GDS. As a matter of fact, in 2012, the Economist estimated that approximately US $\$ 7$ billion was paid by airlines as GDS fees being double the industry's net profit expectation for the year.

\subsection{Limitations of the current distribution system}

While GDS have been taking a significant role in distributing air products from airlines to travel agencies, many observers (e.g. Coza, 2014) estimate that the GDS will no longer be used by 2020. High booking fees and the inherent technical limitations of the distribution system (esp. the limits of today's interfaces and communication standards: Type A/TTY and Type $\mathrm{B} / \mathrm{EDIFACT}$ ) are two main concerns of the airline industry that might lead to the use of the new system or standard in airline distribution (Harteveldt, 2012).

Today the current indirect distribution channel has several major limitations:

- $\quad$ Product commoditization: Airlines cannot personalize their products and services based on customers profile and history (Open Axis Group, 2010). As a consequence the airline's products are fully commoditized and airlines can only compete with other airlines based on two criteria: price or schedule (Open Axis Group, 2010).

- $\quad$ Lack of transparency: The resellers cannot provide transparency of the fares family as provided by airline websites channel (Open Axis Group, 2010).

- No access to rich airlines content: Travel agents cannot provide rich content (e.g. frequent flyer, inventory, and pricing system) as presented in airlines websites to customers (Hoyles, 2015). As a consequence the sale of ancillary products through travel agencies is currently not possible (IATA, 2016a).

- Limited supplier control: Airlines can control and steer their intermediaries only to a limited extend (Open Axis Group, 2010).

- Legacy technology and long development cycle: The technology used by GDS is limited and incompatible with internet-based (XML, web-service) distribution system owned by the airlines (Open Axis Group, 2010).

- $\quad$ Delay of transmitted data (Hoyles, 2015). 


\section{AIRLINE DISTRIBUTION IN THE FUTURE}

\subsection{The IATA initiative: New Distribution Capability}

In early 2012, IATA member airlines agreed during the 34th Passenger Agency Conference in October 2012 on a new program called New Distribution Capability (NDC) to solve limitations of the existing programs in the distribution system and to represent the modernization of air travel distribution (Popovich, 2016).

Hoyles (2015) defines: "NDC is a travel industry-supported program (NDC Program) for the development and market adoption of a new XML-based data transmission standard (NDC Standard)" (Hoyles 2015, p. 4).

This NDC standard is created to enhance communication capability between airlines' computer reservation systems and other participants (e.g. travel agents) in the airline distribution environment. Furthermore, NDC is designed as an open standard also enabling communication between airline systems and technology providers, intermediaries, resellers or other third parties (Hoyles, 2015).

Rationale for this new standard is the IATA Resolution 787 (IATA, 2012) that was adopted by airlines during the 69th IATA Annual General Meeting on June 3rd 2013 in Cape Town. The scope of the resolution is "a standard process [...] for airlines to create their own product offer within their own systems (i.e. assemble fares, schedules and availability - all in one transaction) which will be provided directly by and owned by the airline" (Tyler, 2013).

\subsection{Advantages of New Distribution Capability}

NDC addresses various limitations of the current system shifting from a technology-centric to passenger-centric shopping and booking experience (IATA and Atmosphere Research Group 2016). In particular it would accomplish so by

- $\quad$ providing travel agents with the same capability as airlines' websites, allowing the sale of all primary, ancilliary and promotional air products with more information for the passenger on each product with regards to expected facilities and transparent policies of the products purchased (IATA, 2016a),

- $\quad$ enabling airlines (full service and low cost carriers) to differentiate their products and services to be retailed to different customers (individual and corporate customers) (Hoyles, 2015), 
- $\quad$ helping content aggregators and travel resellers to have access to full and rich contents of the airlines (Hoyles, 2015), and

- $\quad$ providing corporate buyers and leisure travelers a new online shopping experience with a lot of unique and personalized features as they find on retail websites (Popovich, 2016).

NDC will help to replace the outmoded distribution components and help develop the airline distribution system from an airline reservation system to a full retailing platform including real time data, "frictionless" payment transactions and state-of-the-art mobile access (IATA and Atmosphere Research Group 2016).

The NDC standard will also enable airlines CRS to communicate with other airlines' CRS, e.g. Low Cost Airlines who were not using IATA standards for the distribution process (Hoyles, 2015).

To make this concept work, a collaborative approach among the players is highly needed. All players in the industry including airlines, travel agencies, OTAs, GDS, corporate customers, and IT solution providers must work together to ensure that NDC can be implemented and run by all in any circumstances (IATA and Atmosphere Research Group, 2015). Please, refer to figure 4.

Figure 4: New distribution system (Source: IATA, 2016d, pp.12)

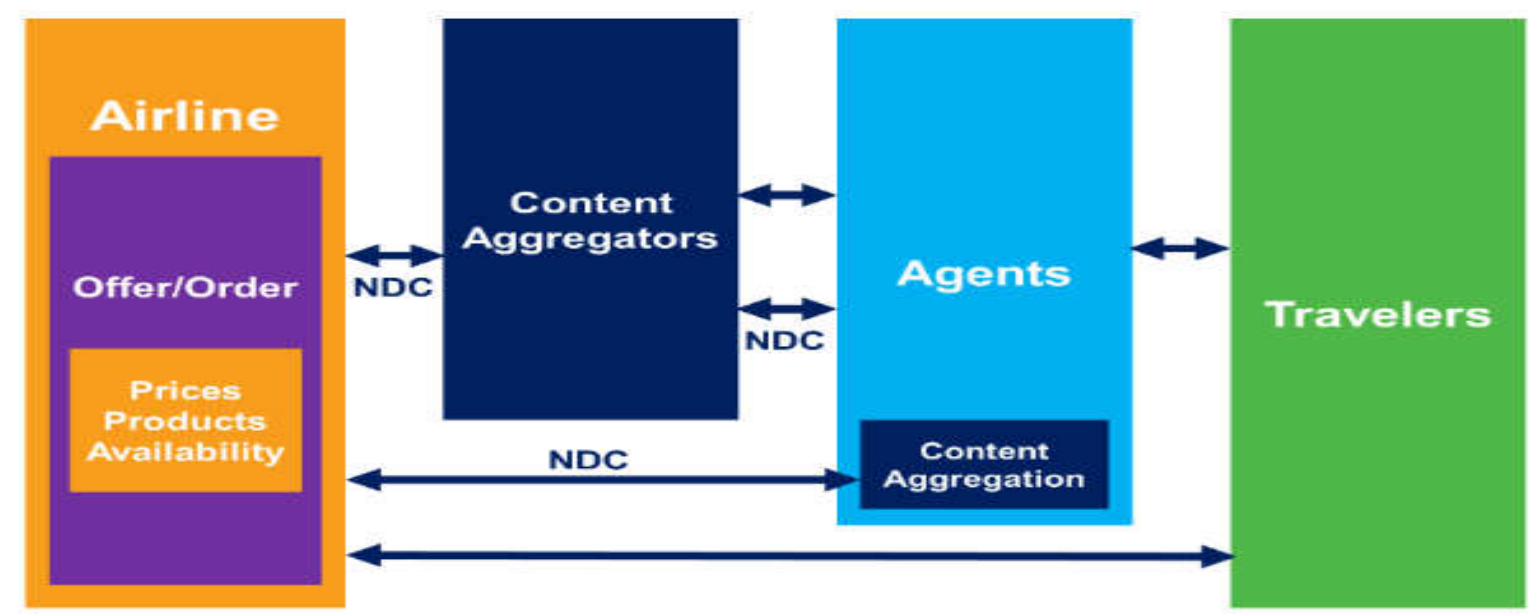

In providing the end-to-end process in airline distribution, the NDC Standard divides the key functional domains into three scopes or schemas (Hoyles, 2015): 
- NDC Shopping, by which airlines can provide rich content and personalization in offering both core and ancillary products and services;

- NDC Order Management (Booking, Payment \& Ticketing, Servicing, Interlining, Reporting, Settlement \& Accounting), which provides new capability to airlines in managing order lifecycle between airlines and resellers covering booking \& servicing and payment \& ticketing;

- NDC Airline Profile, which enables the routing of direct requests from the market to the airline.

Besides, airlines are able to directly communicate with their airline partners through NDC features called NDC Shopping and NDC Order Management (Hoyles, 2015).

\subsection{Regulatory Aspects and Critique}

Since the beginning of the development of the standard, several areas were criticized by different industry stakeholders (Tyler, 2013). The focus was on three of them:

- $\quad$ NDC would contravene privacy laws

- $\quad$ NDC would bypass travel agents and

- $\quad$ NDC would eliminate comparison shopping.

Several travel agent associations have looked into possible privacy law contraventions by the NDC standard and have addressed this issue to regulatory bodies. The European Travel Agents' and Tour Operators' Associations (ECTAA) followed the launch of NDC and participated in hearings of the "Article 29 Data Protection Working Party", an EU advisory body on data protection matters and met with Member States' Data Protection Attachés and the European Data Protection Supervisor. ECTAA addressed data protection concerns to raise awareness on NDC, its incompatibilities with Data Protection provisions and in this respect asked for guidelines (ECTAA, 2014). ECTAA underlines that in Europe, agents are particularly concerned regarding NDC compliance with the EU data protection legislation (ECTAA, 2015). After consulting with several industry associations, the Working Party responded that the NDC initiative may result in a remarkable change in terms of personal data processing associated with operational practices in the air travel market. Because of the uncertainty of the initiative's development, the Working Party does not see itself in a position to adopt a formal opinion on the issue, but will keep it on its agenda (The Article 29 Data Protection Working Party, 2014). 
In the United States the American Society of Travel Agents (ASTA) commented regarding IATA's NDC application with the US Department of Transport (DOT) with an answer to IATA's application serious privacy concerns associated with NDC. The initiative gives the appearance of an unprecedented agreement among horizontal airline competitors on a new business model for the pricing and selling of airline tickets (ASTA, 2013a).

With regards to lack of comparison shopping with the NDC initiative, ASTA noted in its answer that NDC appears to have been designed for the purpose of defeating the fare transparency that the airlines and IATA have publicly confirmed has constrained their ability to raise the prices consumers pay. ASTA quoted that "the most important attribute of the GDSs is their role as industry aggregators." Further "the GDS was essential for comparison shopping, and [...] being able to shop multiple airlines and hotels enables the agent to offer real value to a customer" (ASTA, 2013a).

As part of this discussion, IATA and Open Allies for Airfare Transparency (representing GDSs, travel sellers and other stakeholders) filed in January 2014 a joint motion with additional conditions for approval of Resolution 787 with the DOT (Airlines International, 2014, Airline Business, 2014).

Whilst ASTA recommended the rejection of IATA's NDC application (ASTA, 2013b), the DOT tentatively approved the resolution subject to conditions. Resolution 787 will "create modern, industry-wide technical standards and protocols for data transmission throughout the distribution chain, promoting efficiency, cost savings, and innovation through a real-time exchange of price and service information among carriers, travel agents, customers, and other parties, such as web-based aggregators" (DOT, 2014).

\section{EMPIRICAL ANALYSIS}

\subsection{Data collection}

In 2016, an online survey on the future of airline distribution was conducted among 100 airline distribution experts and 43 experts provided their answers ${ }^{1}$.

The distribution of the respondents in term of economic sector is the following:

- $\quad 48 \%$ were from airlines, mainly in top management positions (e.g. in the area General Management, Distribution, Sales and Marketing, etc.);

\footnotetext{
${ }^{1}$ Please refer to Annex $A$ for detailed results of the survey.
} 
- $\quad 24 \%$ were System Providers;

- $\quad 7 \%$ were in Universities;

- $\quad 4 \%$ worked for Government Agencies \& NGO

- $\quad 2 \%$ were Travel Agencies

- $\quad 15 \%$ were in the residual class "Other"

The survey included two closed and two open questions. In particular, the closed questions allowed the interviewee to provide a 5 scale Likert-Type Response ( $0=$ Not at all, $5=$ very much). On the other hand, in the open questions, the respondents were allowed to rank up to five answers (i.e. I = most important, II = second most important, III = third most important and so on). Three answers were mandatory with the option to give two more answers. The answers have been then clustered and weighted. As for the weight, in particular, every answer mentioned as the most important received 5 points, the second important one 4 points, the third important 3 points and so on.

\subsection{Presentation of the results}

The closed questions produced very important insights in term of assessment of the importance of the NDC and its perceived development stage. In particular, asking airline experts about their opinion whether the current NDC initiative is an important development for the airline distribution industry, the average answer on a scale between 1 ("not at all") and 5 ("very much") is 3.9. Even more important is the distribution of the answers, with more than $73 \%$ of the interviewees agreeing on the fact that NDC could realistically represents a turning point for the airline distribution industry.

The second question, as anticipated before, was aimed at assessing the perceived level of development of NDC and asked if the NDC initiative is either already offering or has the potential to offer the right measures to cover current and perspective issues in the industry. In particular, being asked whether they see the NDC initiative is already offering the right measures to cover today's issues, the average answer is 2.6. This result confirms that market experts believe that NDC is still in its infancy, especially from a technological standpoint, since almost $83 \%$ of the sample answered 2 or 3 on a 5 scale Likert ( $1=$ Not at all; $5=$ very much). However, when the potential to develop is taken into account, the group has certain trust in the IATA initiative and believes with an average answer of 3.7 that NDC can solve tomorrow's challenges in the airline distribution industry. Thus, combining the two results above, we can conclude that albeit the IATA proposition is still perceived as far from being an answer to 
today's issues, it certainly has the potential to represent, in the foreseeable future, a major breakthrough in the airline distribution industry.

The first open question builds on the previous insights and is aimed at understanding what the most critical areas in terms of future development for the industry are. In this regard, the top five items mentioned were:

1. NDC and its customer use;

2. economic model behind airline distribution;

3. cost for development and implementation of new technologies;

4. distribution of ancillary airline products and services; as well as

5. the airlines' ability to control their content in distribution channels.

More specifically, through the analysis of the individual observations, we inferred that when the panel was asked to rank their first most important point of concern, the actual and perspective economic model of the industry as a whole was the most important (business issue), while the data volume related to search and analysis (technological issue) was the close second. NDC and its customer use, being aimed at solving the current business issues through technological innovation, obviously raise some doubts among the panel as far as the current business model is concerned, albeit the same experts recognize its potential value in the next future. This is consistent with what we observed before about the second closed question.

The panel concurred that "security and anti-fraud" as well as "distribution of ancillary airline products and services" are the second most important current issue for the industry. Again, aside from the technological aspect of the concern, the NDC proposition clearly addresses the issue of marketing and distributing ancillary products.

In full support to our last observation, we also noticed that the panel indicated the "airlines' ability to control their content in distribution channels" as the third most important critical factor. Again, the NDC, as largely discussed in the previous sections of this work, will offer a new approach to content dissemination, and in doing so, it will constitute a valid option for overcoming the major limitations of today's distribution channel.

In order to offer a more comprehensive perspective on the airline distribution industry, the last open question regarded the perceived core developments occurred in the past. The first 
three answers ranked by the experts show a high level of concentration around the following themes:

$1^{\text {st }}$ answer: i) Development of GDS and ii) CRS \& ATPCo (auto price function);

$2^{\text {nd }}$ answer: i) Airline Online Sales Channels and ii) IATA resolution 747 (NDC);

$3^{\text {rd }}$ answer: i) Development of E-Ticketing and OTAs (e.g. Orbitz)

As it is possible to infer, despite being still in its infancy stage, NDC has been already ranked among the core development of the industry.

\section{IMPLICATIONS}

\subsection{For airlines}

In the future, by the use of NDC standard, airlines will have wider opportunities to directly interact with intermediaries and reduce commission fees to the GDS. Instead of reducing commission fee that must be paid by airlines to GDS, some people argue that NDC will also create more costs to airlines running the program. Initially airlines have to allocate big investment into this new system, albeit, currently it is unclear how much the cost will be for the airlines (Newcombe, 2014). For many airlines this uncertainty still represents a major concern especially considering their limited financial resources. In addition, many smaller airlines are not even aware of this drastic change and the impacts for their distribution strategy and business models. However, for LCC the new standard offers an opportunity to enlarge their business model towards a hybrid strategy and include indirect channels in their distribution strategy (Klophaus et al., 2012).

\subsection{For GDS Companies}

As for the impact on GDS companies, Svend Leirvaag, Amadeus vice-president, claimed that IATA has derailed air travel industry with NDC questioning its capability to provide rich content to travel agencies, to allow a transparent shopping experience for the customers (Travolution, 2013), and to help creating efficiency in the industry. He expressed his disagreement and resistance towards the NDC program at the CAPA World Aviation Summit 2015 in Helsinki. He was also skeptical, if NDC would be able to deliver the promised results (Taylor, 2015). In this regard, the Global Business Travel Association (GBTA) assumes that the planned airline "profiling" in NDC will disadvantage business buyers and cause differentiated pricing for travelers (Ferguson, 2016). In addition, the revised distribution platform in NDC will lead 
airlines to adopt more direct marketing and sales strategies that will significantly change company travel policies for business travelers (Ferguson, 2016). In the same vein, Elisabeth Martins, Sabre UK commercial director, is questioning the NDC's ability in creating transparency. She is saying "We have serious doubts about transparency and the ability to compare prices. If someone in the industry is on top of technology it is the GDSs, not the airlines" (Travolution, 2013).

These first reactions from GDS companies were caused by uncertainty with regards to the future development of the core business model. Obviously there is a risk that some GDS companies will be reduced to the role of a mere aggregator.

\subsection{For travel agents}

As NDC will enable travel agents to sell the same product range (esp. ancillary products) that airlines offer already today in their direct distribution channels, they will remain in the relevant set of sales points for the buyers and can continue development their own business model based on a full content opportunity.

Due to the shift in power away from the GDSs companies back towards the airlines, it is expected that the kick-backs from GDS companies to travel agents will disappear and possibly be replaced by incentive payments from the airlines. The first steps into this direction have been taken by Lufthansa through charging travel agents for GDS reservations with $16 €$ (Bryan, 2015).

IATA and Atmosphere Research Group 2016 state in their paper on the Future of Airline distribution that third-party retailers remain in the distribution mix while airlines expect their direct channels to account for $45 \%$ of reservations by 2021 (IATA and Atmosphere Research Group 2016).

Online Travel Agents (OTAs) will need to adjust their system with NDC or use an aggregator. This adjustment needs more efforts, cost, and time, but in the end this will benefit them by being able to provide more convenient features to customers in getting new air products shopping experience (O'Neill, 2013). This is also valid for Offline Travel Agents. Long term all travel agents will have cost benefits from a more efficient distribution system. There will be a threat, too, from new disruptive entrants like CAFGA² for travel agents (and GDS companies, too).

\footnotetext{
${ }^{2}$ Concur, Apple, Facebook, Google and Amazon.
} 


\subsection{For Travelers}

An IATA study from 2015 stated that passengers would welcome NDC. More than $75 \%$ of air travelers said that compared to today, NDC-based displays would make it easier to compare and understand flights, prices and costs. More than $70 \%$ of business fliers and $65 \%$ of leisure fliers would be more likely to purchase optional airline services (Airlines International, 2015).

\subsection{Other participants in the airline distribution chain}

In addition, the NDC roll-out will also involve IT providers that directly support the airline distribution system, and this is automatically leading to supplementary works for IT companies (O'Neill, 2013). Besides, NDC and the change in airline systems will also impact Airline Tariff Publishing Company (ATPCO), OAG (Air Travel Intelligence), and other fare filing companies (O’Neill, 2013).

\subsection{For new and/or disruptive Industry Players}

In 2014, IATA launched in cooperation with investment firms a five million US-dollar NDC Innovation Fund (NDCIF) to attract start-ups to NDC and to provide opportunities for an innovative travel industry (Airlines International, 2014). In 2016 and after one shareholder of the NDCIF withdraw its participation due to current economy and market conditions, IATA was seeking new investors (Airlines International, 2016b).

While airlines in the past focused on their established direct and indirect distribution channels, new players having no history in airline distribution but in e-commerce, are today scrutinizing the system (Harteveldt, 2012):

- $\quad$ Concur with its travel reporting software "TripIt" enables customers to consolidate their travel plans in one "Super-PNR", collecting massive volumes of customer data and insights that no transport or travel service provider could collect itself. Eventually Concur may sell this passenger intelligence to airlines and other interested stakeholders in passenger travel.

- $\quad$ Apple offers with passbook a virtual wallet solution which stores various documents and information of the customer such as frequent traveler cards, boarding passes and other admission tickets. By offering the consumer an easy and functional solution, Apple puts itself between the airlines and the customers, is collecting additional information about the customers and may commercialize the airlines' access to the customer. 
- With its giant social media platform, Facebook is collecting as many details as possible from its users, including search and geographic data. In combination with its ability to process shopping transactions, Facebook would be able to create a travel value platform that could pit airlines against intermediaries to reach travelers, knowing exactly the interests and needs of its users.

- Google has built a virtual environment with social media platforms, operating systems, hardware, online stores, data aggregating and meta search solutions and much more. Being so deeply and widely integrated into the traveler's everyday life, Google may facilitate or interfere with the relationship an airline has with its customers - controlling the channels an airline could use to have access to its customers or even monetize the access.

- Besides its own wallet solution, Amazon has defined the customer's e-commerce experience and expectations. Eventually, Amazon may directly enter the airline distribution arena; until then it surely hosts travel websites on its Amazon Web Services and continues to influence the way customers want to shop.

\section{THE IMPLEMENTATION OF NDC}

In 2014, there have been 8 airlines participating in NDC pilots and 3 airlines in live transactions. Participating airlines shared their findings in implementing NDC covering the themes of project startup wins, schemas, handling rich content, and the offer management concept. Besides, new implementers also requested IATA use cases illustration through sample schemas instances (Drake, 2015).

Swiss International Air Lines (LX) is one of the participating airlines in a NDC Pilot in cooperation with three leading IT providers; PROS, Datalex, and HP Enterprise Services. They launched the project to demonstrate integrated merchandising, revenue optimization, and fulfillment against the SWISS CRS/PSS for an agency point of sale (Drake, 2015). Please, refer to figure 5 .

Within two years, there is a significant increase in the numbers of airlines and travel agents deploying NDC. In 2015, as it is possible to infer from the following figure 6, there have been 16 airlines participating in NDC pilot and 11 of them have delivered live transactions (Courtas, 2016). Besides, airlines have also already implemented NDC functionalities; 12 airlines 
implemented offer and order management, 3 airlines implemented offer management, and 1 airline implemented post booking ancillary (Courtas, 2016).

Figure 5: The results of dynamically priced offers from Swiss (Drake 2015)

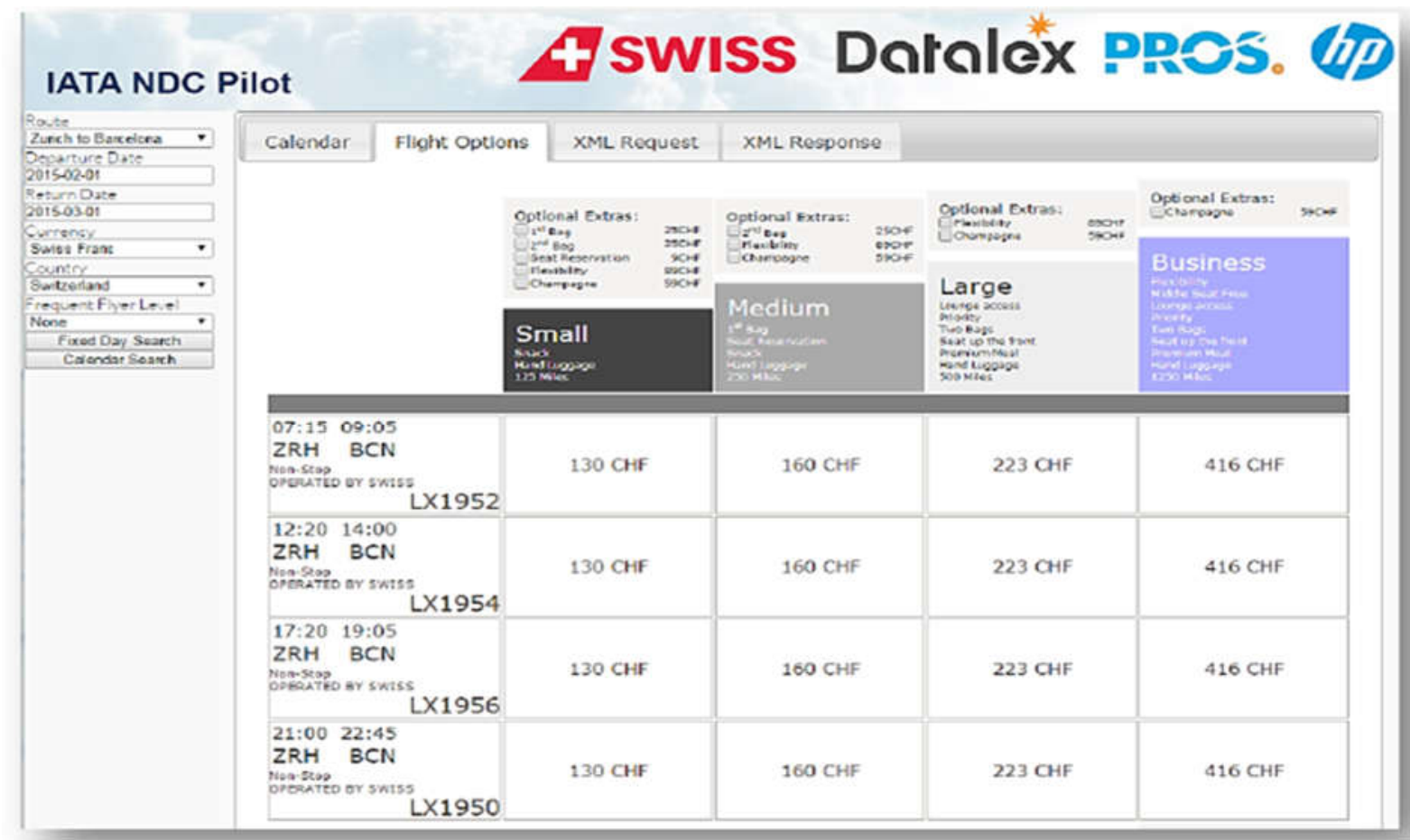

Figure 6: NDC Pilot participants in 2015 (Courtas 2016)

\begin{tabular}{|c|c|c|}
\hline Airline & IT Providers/Aggregators* & Travel Agent(s) \\
\hline Aer Lingus (EI) & Airline IT department & Club Travel \\
\hline Air China $(\mathrm{CA}) \rightarrow$ & Travelsky Technology Limited & China Air Service \\
\hline American Airlines (AA) $\rightarrow$ & Reserve, Farelogix & Copastur \\
\hline British Airways (BA) $\rightarrow$ & Airline IT Department & Skyscanner, other undisclosed agent \\
\hline China Southern Airlines $(\mathrm{CZ})+$ & Airline IT department & Ctrip \\
\hline Flybe (BE) & $\begin{array}{l}\text { Hewlett Packard Enterprise, } \\
\text { Travelfusion* }\end{array}$ & $\begin{array}{l}\text { Selected travel agents through } \\
\text { Travelfusion }\end{array}$ \\
\hline GOL Linhas Aereas (G3) $\rightarrow$ & Navitaire, Reserve ${ }^{\star}$ & Flytour, Rextur-Advance \\
\hline Hainan Airlines $(\mathrm{HU})+$ & Travelsky Technology Limited & CTBA \\
\hline Heli Air Monaco $(\mathrm{YO})+$ & Resiber, APG-Orchestra & To be coming \\
\hline InselAir $(7 \mathrm{I}) \rightarrow$ & JR technologies, SITA & InselAir affiliated TMC \\
\hline Qantas (QF) & Airline IT department & $\begin{array}{l}\text { Selected travel agents through } \\
\text { Helloworld }\end{array}$ \\
\hline Qatar Airways (QR) $\rightarrow$ & Farelogix & GTV Tours \\
\hline Rotana Jet Aviation $(R G)+$ & TPConnects* & $\begin{array}{l}\text { Asia Group of Companies (Asia } \\
\text { Travel) }\end{array}$ \\
\hline Scoot $(T Z)$ & Navitaire, Travelfusion & TBC \\
\hline Shandong Airlines (SC) $\rightarrow$ & Travelsky Technology Limited & Qingdao Huajun Air Service \\
\hline Siberia Airlines (S7) & Openjaw, Ontravelsolutions & Onetravel Minsk \\
\hline
\end{tabular}

* IT providers with aggregation function in terms of their role in the pilot

$\rightarrow$ Airlines with live transactions in 2015 
Beyond NDC pilots, a number of airlines have implemented the NDC standard for a specific business case (IATA, 2016b):

- $\quad$ British Airways has implemented an NDC based communication with Skyscanner for metasearch search and sale for British Airways ancillary products (Skyscanner, 2015).

- Condor has implemented order and offer management for its new reservation environment for UK travel agents (Pribas, 2016).

- $\quad$ Emirates has implemented NDC shopping schemas to provide access to its ancillary products (Emirates, 2016).

- $\quad$ Seven Asian low cost carriers joined a pan-regional low cost carrier alliance and use an interline platform with NDC standard to exchange flight schedules and ancillary product information (Cebu Pacific, 2016, ATW, 2016).

- United Airlines implemented shopping schemes to sell dynamically-priced Economy Plus seating (IATA, 2016c).

\section{CONCLUSION}

Airline distribution systems keep changing in accordance to market trends and technology. Approximately $50 \%$ of all airline bookings are nowadays generated via internet-based direct distribution channels such as airlines' websites, taking away bookings from the indirect channels which had managed around $80 \%$ of the bookings in the past.

Cost in selling tickets through indirect channels is 20 -times more expensive compared to direct channels due to the fees that have to be paid by airlines to the intermediaries. To avoid these costs, most low cost carriers focused on sales through their own website. However, airlines websites cannot be used by network airlines to sell their airline partners' tickets without involving a GDS. GDS is still playing a significant role for mainly full service airlines to generate more revenue from selling other networks. Besides, GDS also enables travel agencies to sell tickets of different airlines. On the other hand, GDS has no capability to provide travel agents rich content as found in airlines website. Therefore, high booking fee and the other limitations of the GDS become two main concerns of the airline industry that might lead to the use of new system or standard in distribution channel. 
To respond to the current situation and future anticipation, IATA has initiated a new airline distribution standard called New Distribution Capability (NDC). NDC is not a new system to replace the GDS, but a communication standard enabling airlines, IT providers, and resellers (mainly travel agencies) to work together on new distribution capabilities.

NDC promises a lot of advantages to the industry: product differentiation, faster delivery and promotion of new products to the market, personalization on specific products and customers, and an access to full and rich content of the airlines. Travel agencies and resellers will be able to do product and service comparisons among airlines, and customers will get a transparent shopping experience.

But the implementation of NDC will also create consequences for airlines, GDS companies, travel agents, IT providers and new entrants. Some people argue that NDC will create high cost for airlines as they will have to allocate big investments to this new system. The introduction of NDC is predicted to weaken the position of the GDSs. Besides, travel agents fear that NDC will enable airlines to directly charge booking fees to travel agents that could result in higher cost for the travelers. Online travel agents have to invest more money, effort, and time to adjust their current system to the NDC standard.

By combining the insights gained through the non-empirical literature review section with the empirical results from our airline business expert survey, we tentatively describe NDC's strengths, weaknesses, opportunities and threats in the following table.

Table 1: NDC SWOT Analysis

\section{STRENGTHS}

- Passenger-centric business concept: passengers have a more customized shopping experience

- Enables airlines to present and package their products in a more complete way (e.g. Ancillary products)

- Providing travel agents with the full access to airlines' rich content

- Reducing distribution fee commission

- Enhancing close collaboration among the players

- Enabling direct communication between airlines, travel agents and passengers

\section{WEAKNESSES}

- Requiring system adjustment from airlines and travel agents resulting in costly investments

- Old technology is stable and makes a fast exchange of information possible; new and complex concept might lead to instable transactions

- Compliance to EU data protection legislation 
- Industry sees the potential of NDC, but acknowledges that a technological and business gap has to be filled

- Fostering simplification of business processes

- Airlines are able to redefine the value chain

- Opening of new revenue sources for airlines

- New market opportunities for newcomers such as Concur, Apple, Google, Amazon, and Facebook
- Technical integration might be challenging

- Improper implementation due to lack of education and planning

- GDS might improve their own capability for trading ancillary products by updating their It systems and mobile compatible software tools

- Loss of revenue for the GDS

- Biased offer for business and private travelers/ travel agents

Since 2013, IATA initiated the deployment of NDC Pilots and the numbers of airlines participating in these pilot projects have been increasing year over year. By 2015, there have been 16 airlines participating and 11 of them have been engaged in live transaction. For a better implementation in the future, the participating airlines publically share their technical and non-technical findings with IATA to enable further improvements.

\section{REFERENCES}

1. Airline Business (2014). Analysis: Airlines eye Amazon-style retail experience. Airline Business. March 2014.

2. Airlines International (2014). NDC: A venture for all sorts. [online] Available from: http://airlines.iata.org/analysis/ndc-a-venture.-for-all-sorts. [Accessed: 16th August 2016].

3. Airlines International (2015). Passengers see travel booking advantages in New Distribution Capability. [online] Available from: http://airlines.iata.org/agenda/passegners-see-travel-booking-advantages-in-newdistrbuition-capability. [Accessed: 16th September 2016].

4. Airlines International (2016). Airline uptake of NDC advances. [online] Available from: http://airlines.iata.org/agenda/airline-uptake-of-ndc-advances. [Accessed: 16th August 2016].

5. Airlines International (2016b). New Distribution Capability funds seeks investors. [online] Available from: http://airlines.iata.org/agenda/new-distribution-capability-fund-seeksinvestors. [Accessed: 16th September 2016].

6. ASTA (2013a). Answer of the American Society of Travel Agents to Application for Approval of IATA Resolution 787. Docket No. OST-2013-0048. 01 May 2013.

7. ASTA (2013b). ASTA recommends rejection of IATA NDC application. [online] Available from: 
http://www.asta.org/News/PRdetail.cfm?ItemNumber=10351\&navItemNumber=491. [Accessed: 2nd August 2016].

8. ATW (2016). Asia-Pacific LCCs join forces in new Value Alliance. Air Transport World. June 2016.

9. Bryan (2015). Lufthansa CFO believes other airlines will follow with GDS charge. [online] Available from: http://www.reuters.com/article/2015/07/30/lufthansa-results-charge. [Accessed: 7th August 2015].

10. Cheng, K., Lee, Z.-H., Shomali, H. (2012). Airline firm boundry and ticket distribution in electronic markets. International Journal of Production Economics: 137 (2012) 137-144.

11. Cebu Pacific (2016). CEB joins world's first pan-regional LCC alliance. [online]. Available from: https://www.cebupacificair.com/about-us/Pages/news.aspx?id=1066. [Accessed: 1st August 2016].

12. Courtas, V. (2016). NDC 2015 Pilots Report. International Air Transport Association.

13. Coza, D. (2014). Why is GDS important to the travel industry?. [online] Available from: http://tts.com/blog/why-gds-is-important-travel-industry. [Accessed: 14th March 2016].

14. Department of Transport (DOT). 2014. Order 2014-5-7. Action on IATA Agreement. Docket OST-2013-0048. 21 May 2014.

15. ECTAA (2014). ECTAA Activity Report 2013/2014.

16. ECTAA (2015). ECTAA Activity Report 2014/2015.

17. Emirates (2016). Emirates enhances connectivity for travel agents with NDC compliant online B2B API. Available from: http://www.emirates.com/media-centre/emiratesenhances-connectivity-for-travel-agents-with-ndc-compliant-online-b2b-api\#. [Accessed: 1st August 2016].

18. Drake, S. H. (2015). NDC 2014 Pilot Consolidated Report. International Air Transport Association. [online]. Available from: https://www.iata.org/whatwedo/airlinedistribution/ndc/Documents/2014-ndc-pilot-year-end-report.pdf. [Accessed: $28^{\text {th }}$ July 2017].

19. Ferguson, M. (2016). NDC: GBT weights in. online] Available from: http://www.gbta.org/magazine/Pages/Leverage_Mar_April.aspx. [Accessed: 16th March 2016].

20. Harteveldt, H. H. (2012). The Future of Airline Distribution; A Look Ahead to 2017. Atmosphere Research Group.

21. Hoyles, Y. (2015). New Distribution Channel (NDC): Together Let's Build Airline Retailing. IATA Strategy Paper version 1.2.

22. IATA (2012). Resolution 787. Enhanced Airline Distribution. 34th Passenger Agency Conference Manual 2013.

23. IATA (2013). Business Requirements Documents NDC 1: Airline Shopping. 23 October 2013. [online]. Available from: http://www.iata.org/whatwedo/airlinedistribution/ndc/Documents/ndc-brds-20160920.zip. [Accessed: 14 $4^{\text {th }}$ July 2017].

24. IATA (2015). IATA Air Passenger Forecast Shows Dip in Long-Term Demand. 26 November 2015. [online]. Available from: http://www.iata.org/pressroom/pr/Pages/2015-11-2601.aspx. [Accessed: $28^{\text {th }}$ July 2017].

25. IATA (2016a). New Distribution Channel (NDC): Together Let's Build Airline Retailing. October 2015. [online]. Available from: http://www.iata.org/events/Documents/wps2015together-lets-build-retailing.pdf. [Accessed: $14^{\text {th }}$ July 2017]. 
26. IATA (2016b). New Distribution Capability. [online]. Available from: http://www.iata.org/whatwedo/airline-distribution/ndc/Pages/default.aspx. [Accessed: 1st August 2016].

27. IATA (2016c). New Distribution Capability - Detailed Airline Status Report. June 2016.

28. IATA (2016d). NDC Standard Implementation Guide 2.0. December 2016. [online]. Available from: http://www.iata.org/whatwedo/airline-distribution/ndc/Documents/ndcimplementation-guide.pdf. [Accessed: $14^{\text {th }}$ July 2017].

29. IATA, WTAAA, T2 Impact, and Atmosphere Research Group (2015). NDC: Travel Agencies' Enabler to Success. October 2015.

30. IATA and Atmosphere Research Group (2015). Atmosphere NDC PAX Report.

31. IATA and Atmosphere Research Group (2016). The Future of Airline Distribution, 2016 2021. October 2016.

32. Kayak.com (2016). Kayak.com online portal. [online] Available from: https://www.kayak.com/flights. [Accessed: 4th April 2016].

33. Klophaus, R., Conrady, R., Fichert, F. (2012). Low cost carriers going hybrid: Evidence from Europe. Journal of Air Transport Management: 23 (2012) 54-58.

34. Kothari, C. R. (2004). Research Methodology - Methods and Techniques. 2nd Ed. New Delhi: New Age International Publisher.

35. Newcombe, T. (2014). Just what exactly is NDC?. [online] Available from: http://buyingbusinesstravel.com/feature/0222557-just-what-exactly-ndc [Accessed: 16th March 2016].

36. O'Connell, J.F., Williams, G. (2011). Air Transport in the 21st Century. Surrey: Ashgate Publishing Company.

37. O'Neill, S. (2013). The real NDC: Decoding the planned (r)evolution in airline distribution by IATA and airlines. [online] Available from: https://www.tnooz.com/article/the-real-ndcdecoding-the-planned-revolution-in-airline-distribution-by-iata-and-airlines/. [Accessed: 16th March 2016].

38. Open Axis Group (2010). Distribution 2.0: Innovating the Airline Indirect Channel.

39. Popovich, A. (2016). Understanding IATA's New Distribution Capability. [online] Available from: http://ttgasia.com/article.php?article_id=20740. [Accessed: 7th March 2016].

40. Pribas (2016). NDC Level 3 Certification. [online]. Available from: http://www.pribas.info/\#!NDC-Level-3-Certification/fjf9u/577f9f5f0cf21e6e1ebdc63e. [Accessed: 1st August 2016].

41. Qatar Airways (2017). Qatar Airways online portal. [online] Available from: https://booking.qatarairways.com/nsp/views/index.xhtml. [Accessed: 15th August 2017].

42. Shaw, S. (2011). Airline Marketing and Management. Surrey: Ashgate Publishing Company.

43. Shon, Z., Chen, F., Chang, Y. (2003). Airline e-commerce: the revolution in ticketing channels. Journal of Air Transport Management: 9 (2003) 325-331.

44. Skyscanner (2015). Skyscanner to be first metasearch with capacity to display and sell tickets using NDC standard. [online]. Available from: https://www.skyscanner.net/blogs/skyscanner-be-first-metasearch-capacity-display-andsell-tickets-using-ndc-standard. [Access: 1st August 2016].

45. Taneja, N.K. (2011). The Passenger has Gone Digital and Mobile. Surrey: Ashgate Publishing Company. 
46. Taylor, I. (2015). IATA 'derailed industry' with NDC, claims Amadeus vice-president. Travel Weekly: October 8th, 2015.

47. Tyler, T. (2013). State of the Air Transport Industry. [online] Available from: http://www.iata.org/events/agm/2013/Pages/videos.aspx?vid=16. [Accessed: 11th June 2016].

48. The Economist (2012). The ineluctable middlemen. [Online] Available from: http://www.economist.com/node/21560866. [Accessed: 14th March 2016].

49. Travolution (2013). IATA under fire as GDSs hit out at New Distribution Capability. [Online] Available from: http://www.travolution.co.uk/Articles /2013/05/13/6717/iata+under+fire+as+gdss+hit+out+at+new+distribution.html. [Accessed: 16th March 2016].

50. Article 29 Data Protection Working Party (2014). Letter dated 26 September 2014. 


\section{Annex: Results of the Online Survey}

The online survey was conducted with Airline Distribution Specialists during March 2016 through Survey Monkey. A total of 46 responses were collected.

From those 46 responses, 22 came from specialists working in the airline industry, 11 from specialists working for system providers, 3 from universities, 2 from Government Agencies or NGOs and one from a travel agency. 7 responses came from specialists working in other industries. $^{3}$

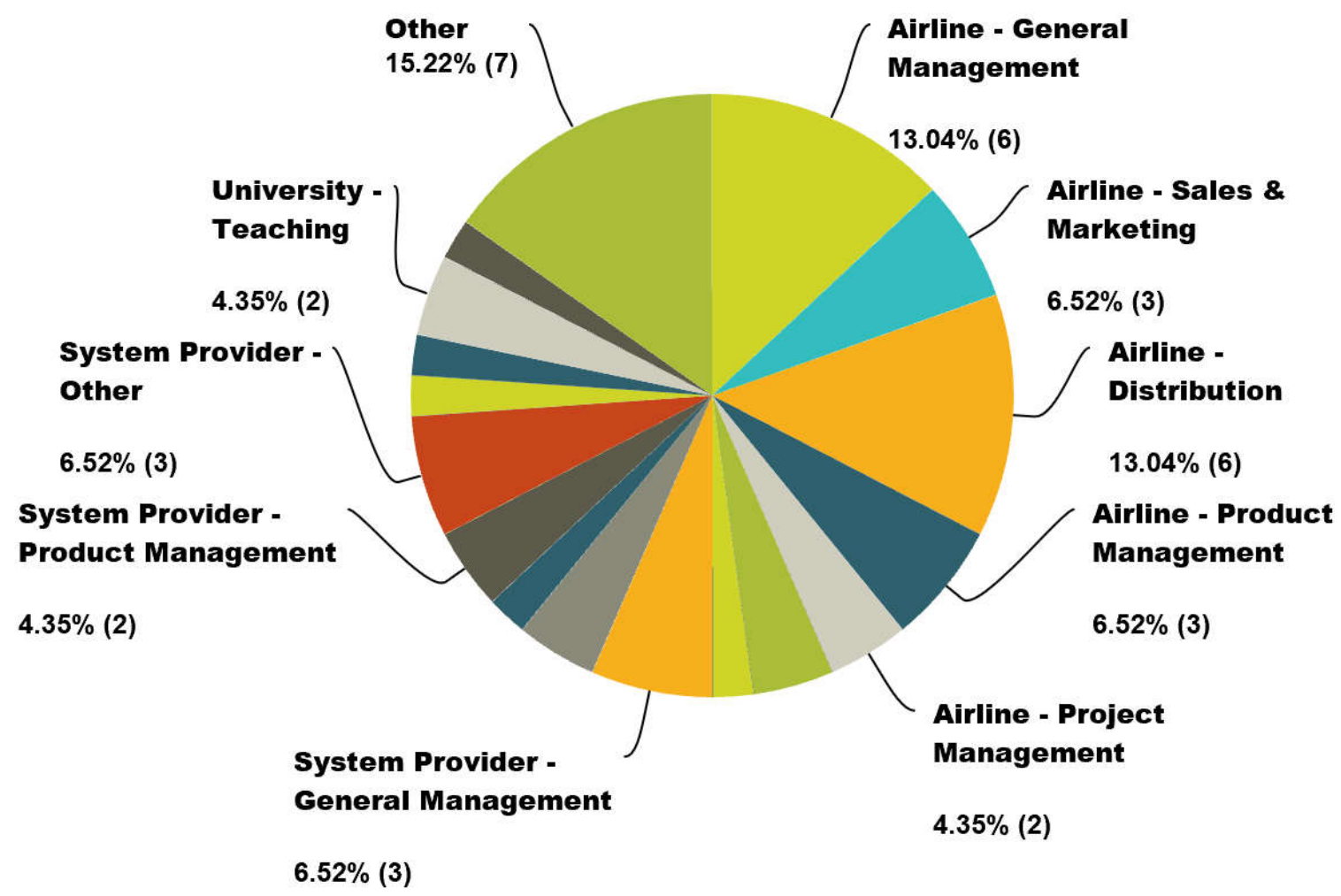

\begin{tabular}{|c|c|c|}
\hline \multicolumn{1}{|l|}{ Role } & \multicolumn{2}{|c|}{ Responses } \\
\hline Airline & $\mathbf{4 7 . 8 4 \%}$ & $\mathbf{2 2}$ \\
\hline Airline - General Management & $13.05 \%$ & 6 \\
\hline Airline - Sales \& Marketing & $6.52 \%$ & 3 \\
\hline Airline - Distribution & $13.05 \%$ & 6 \\
\hline Airline - Product Management & $6.52 \%$ & 3 \\
\hline Airline - Project Management & $4.35 \%$ & 2 \\
\hline Airline - Other & $4.35 \%$ & 2 \\
\hline
\end{tabular}

${ }^{3}$ The following graph and table shows only those categories that were mentioned by at least one specialist. 


\begin{tabular}{|c|c|c|}
\hline Travel Agency & $\mathbf{2 . 1 7 \%}$ & $\mathbf{1}$ \\
\hline Travel Agency - Distribution & $2.17 \%$ & 1 \\
\hline System Provider & $\mathbf{2 3 . 9 1 \%}$ & $\mathbf{1 1}$ \\
\hline System Provider - General Management & $6.52 \%$ & 3 \\
\hline System Provider - Sales \& Marketing & $4.35 \%$ & 2 \\
\hline System Provider - Distribution & $2.17 \%$ & 1 \\
\hline System Provider - Product Management & $4.35 \%$ & 2 \\
\hline System Provider - Other & $6.52 \%$ & 3 \\
\hline Government Agencies \& NGOs & $\mathbf{4 . 3 4 \%}$ & $\mathbf{2}$ \\
\hline Government - Standards \& Regulation & $2.17 \%$ & 1 \\
\hline NGOs - Other & $2.17 \%$ & $\mathbf{3}$ \\
\hline Universities & $\mathbf{6 . 5 2} \%$ & 2 \\
\hline Universities - Teaching & $4.35 \%$ & 1 \\
\hline Universities - Research & $2.17 \%$ & $\mathbf{7}$ \\
\hline Other & $\mathbf{1 5 . 2 2 \%}$ & $\mathbf{4 6}$ \\
\hline TOTAL & $\mathbf{1 0 0 \%}$ & \\
\hline
\end{tabular}

During the survey the participants were asked their opinion about today's and tomorrow's importants of IATA's New Distribution Capability (NDC) Program by choosing the corresponding value on a scale from 1 ("not at all") to 5 ("very much") or 0 ("I don't know").

The first question asked was: "Do you consider the current NDC initiative being an important or very important development or milestone for the airline distribution industry?" The average of all 46 answers was 3.93:

\begin{tabular}{|c|c|c|c|c|c|c|}
\hline \multicolumn{7}{|c|}{ "Important or very important development or milestone" } \\
\hline $\begin{array}{c}\text { Not at all } \\
1\end{array}$ & 2 & 3 & 4 & $\begin{array}{c}\text { Very much } \\
5\end{array}$ & $\begin{array}{c}\text { Don't know } \\
0\end{array}$ & Average \\
\hline 0 & 6 & 6 & 19 & 15 & 0 & \multirow{2}{*}{3.93} \\
\hline $0 \%$ & $13.04 \%$ & $13.04 \%$ & $41.31 \%$ & $32.61 \%$ & $0 \%$ & \\
\hline
\end{tabular}

The second question asked was: "Do you see the NDC initiative already offering or having the potential to develop the right measures to cover today's issues and to solve tomorrow's challenges in the airline distribution industry?" The average of all 
46 answers with regards to the question whether NDC is already offering the right measures was 2.58, while the average with regards to the question whether NDC has potential to develop the right measures in future was 3.76:

\begin{tabular}{|c|c|c|c|c|c|c|}
\hline \multicolumn{7}{|c|}{ "Already offering" } \\
\hline $\begin{array}{c}\text { Not at all } \\
1\end{array}$ & 2 & 3 & 4 & 5 & 0 & \\
\hline 2 & 22 & 16 & 3 & 2 & 1 & \multirow{2}{*}{2.58} \\
\hline $4.35 \%$ & $47.83 \%$ & $34.78 \%$ & $6.52 \%$ & $4.35 \%$ & $2.17 \%$ & \\
\hline
\end{tabular}

\begin{tabular}{|c|c|c|c|c|c|c|}
\hline \multicolumn{7}{|c|}{ "Potential to develop" } \\
\hline $\begin{array}{c}\text { Not at all } \\
1\end{array}$ & 2 & 3 & 4 & 5 & 0 & \\
\hline 1 & 4 & 13 & 14 & 13 & 1 & \multirow{2}{*}{3.76} \\
\hline $2.17 \%$ & $8.70 \%$ & $28.26 \%$ & $30.43 \%$ & $28.26 \%$ & $2.17 \%$ & \\
\hline
\end{tabular}

In form of an open question, the 43 airline industry specialists were asked: "What are - in your opinion - today's most important issues and tomorrow's challenges in the airline distribution industry?".

Participants were allowed to give up to five answers to this questions with the first answer being the most important, the second answer the second most important, the third answer the third most important and so on. Three answers were mandatory with the option to give two more answers. The answers were then analyzed, arranged in groups and weighted: every answer mentioned as the most important received 5 points, the second important one 4 points, the third important 3 points and so on. All points for the answers in one group were then summed up. The five mostly mentioned areas with highest importance were:

\begin{tabular}{|l|c|}
\hline Grouped Items and Topics & Weight \\
\hline NDC and its customer use & 58 \\
\hline The economic model behind airline distribution & 53 \\
\hline Cost for development and implementation of new technologies & 47 \\
\hline Distribution of ancillary airline products and services & 37 \\
\hline The airlines' ability to control their content in distribution channels & 29 \\
\hline
\end{tabular}


Detailed answers were:

To complete the picture, this question was combined with another open question to the specialists: "What are - in your opinion - the most important past developments and milestones in the airline distribution industry?" The answers were again analyzed, arranged in groups and weighted as described above. Detailed answers were:

\begin{tabular}{|c|c|c|c|c|c|c|}
\hline $\begin{array}{c}\text { mentioned } x \text { times as } \\
\text { Grouped Items and Topics }\end{array}$ & $\begin{array}{c}\text { 1st } \\
\text { answer }\end{array}$ & $\begin{array}{c}\text { 2nd } \\
\text { answer }\end{array}$ & $\begin{array}{c}\text { 3rd } \\
\text { answer }\end{array}$ & $\begin{array}{c}\text { 4th } \\
\text { answer }\end{array}$ & $\begin{array}{c}\text { 5th } \\
\text { answer }\end{array}$ & Result \\
\hline NDC and its Customer Use & 5 & 3 & 5 & 2 & 2 & 58 \\
\hline $\begin{array}{l}\text { The economic model behind } \\
\text { airline distribution }\end{array}$ & 7 & 1 & 1 & 4 & 3 & 53 \\
\hline $\begin{array}{l}\text { Cost for development and } \\
\text { implementation of new } \\
\text { technologies }\end{array}$ & 4 & 3 & 3 & 3 & & 47 \\
\hline $\begin{array}{l}\text { Distribution of ancillary airline } \\
\text { products and services }\end{array}$ & 2 & 4 & 2 & 2 & 1 & 37 \\
\hline $\begin{array}{c}\text { The airlines' ability to control } \\
\text { their content in distribution } \\
\text { channels }\end{array}$ & 1 & & 8 & & & 29 \\
\hline Security and anti-fraud & & 5 & 2 & 1 & 1 & 29 \\
\hline $\begin{array}{l}\text { Data Volume for Search and } \\
\text { Analysis }\end{array}$ & 5 & & & 1 & & 27 \\
\hline $\begin{array}{c}\text { GDS Monopoly Disruption ("LH } \\
16 \text { EUR GDS Fee" Case) } \\
\end{array}$ & 2 & 1 & 2 & 2 & 1 & 25 \\
\hline Reduction in Complexity & 2 & 2 & 1 & & & 21 \\
\hline $\begin{array}{l}\text { Further Development of Mobile } \\
\text { Commerce and Social Media }\end{array}$ & 1 & 1 & 2 & 2 & 1 & 20 \\
\hline Metasearch and "CAFGA" & 2 & 1 & 1 & & & 17 \\
\hline Interoperability & 1 & 2 & 1 & & & 16 \\
\hline Payment Solutions & 2 & & 1 & 1 & & 15 \\
\hline Further (De)regulation & 1 & 1 & 1 & 1 & & 14 \\
\hline Real Time Pricing & & 3 & & & & 12 \\
\hline Managing Transition & & 3 & & & & 12 \\
\hline ONE Order & & 1 & & 2 & 1 & 9 \\
\hline $\begin{array}{c}\text { Optimizing Direct Channel } \\
\text { Performance }\end{array}$ & 1 & & 1 & & & 8 \\
\hline $\begin{array}{c}\text { Price Transparency and } \\
\text { Competition }\end{array}$ & 1 & & 1 & & & 8 \\
\hline Product Differentiation & & 2 & & & & 8 \\
\hline
\end{tabular}




\begin{tabular}{|c|c|c|c|c|c|c|}
\hline $\begin{array}{c}\text { mentioned } x \text { times as } \\
\text { Grouped Items and Topics }\end{array}$ & $\begin{array}{c}\text { 1st } \\
\text { answer }\end{array}$ & $\begin{array}{c}\text { 2nd } \\
\text { answer }\end{array}$ & $\begin{array}{c}\text { 3rd } \\
\text { answer }\end{array}$ & $\begin{array}{c}\text { 4th } \\
\text { answer }\end{array}$ & $\begin{array}{c}\text { 5th } \\
\text { answer }\end{array}$ & Result \\
\hline Development of GDS & 9 & 4 & 2 & 2 & & 71 \\
\hline CRS \& ATPCo (auto price function) & 8 & 6 & 1 & 1 & & 69 \\
\hline Airline Online Sales Channels & 5 & 6 & 3 & 2 & 1 & 63 \\
\hline Development of E-Ticketing & 5 & 3 & 5 & 2 & 3 & 59 \\
\hline OTAs (such as Orbitz) & 1 & 2 & 6 & 3 & 2 & 39 \\
\hline IATA Resolution 747 (NDC) & 1 & 5 & 4 & & 1 & 38 \\
\hline (De)regulation & 2 & 2 & 3 & 2 & 1 & 32 \\
\hline Internet Technology & 3 & 2 & & 2 & 1 & 28 \\
\hline AIRIMP Standards & 2 & & & 3 & & 16 \\
\hline Sale of Ancillary Products & & 1 & 3 & 1 & 1 & 16 \\
\hline Mobile Booking Solutions & 1 & 1 & & 1 & 2 & 13 \\
\hline Low Fare Shopping Engines & 1 & & 2 & & & 11 \\
\hline Ticketless Solutions & 1 & 1 & & & & 9 \\
\hline Airline Alliances & & 1 & 1 & & 1 & 8 \\
\hline Interline & & & 2 & 1 & & 8 \\
\hline EMD Standard & & 1 & 1 & & & 7 \\
\hline IATA StB & & 1 & 1 & & & 7 \\
\hline Safety & 1 & & & & 1 & 6 \\
\hline Discontinuation of Commission & & 1 & & 1 & & 6 \\
\hline Codeshare & & & 1 & 1 & 1 & 6 \\
\hline
\end{tabular}

